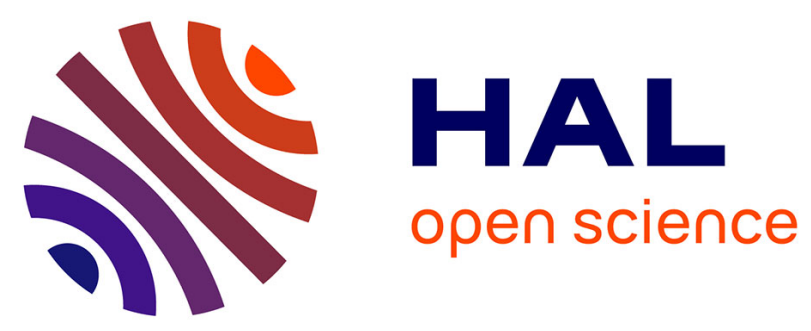

\title{
Detection of foot-and-mouth disease virus from culture and clinical samples by reverse transcription-PCR coupled to restriction enzyme and sequence analysis
} Margarita Sáiz, Diana de La Morena, Esther Blanco, José Núñez, Rufino Fernández, José Sánchez-Vizcaíno

\section{To cite this version:}

Margarita Sáiz, Diana de La Morena, Esther Blanco, José Núñez, Rufino Fernández, et al.. Detection of foot-and-mouth disease virus from culture and clinical samples by reverse transcription-PCR coupled to restriction enzyme and sequence analysis. Veterinary Research, 2003, 34 (1), pp.105-117. 10.1051/vetres:2002059 . hal-00902610

\section{HAL Id: hal-00902610 https://hal.science/hal-00902610}

Submitted on 1 Jan 2003

HAL is a multi-disciplinary open access archive for the deposit and dissemination of scientific research documents, whether they are published or not. The documents may come from teaching and research institutions in France or abroad, or from public or private research centers.
L'archive ouverte pluridisciplinaire HAL, est destinée au dépôt et à la diffusion de documents scientifiques de niveau recherche, publiés ou non, émanant des établissements d'enseignement et de recherche français ou étrangers, des laboratoires publics ou privés. 
Original article

\title{
Detection of foot-and-mouth disease virus from culture and clinical samples by reverse transcription-PCR coupled to restriction enzyme and sequence analysis
}

\author{
Margarita SÁIZ $^{\mathrm{a} *}$, Diana B. DE LA MORENA ${ }^{\mathrm{a}, \mathrm{b}}$, Esther BLANCO ${ }^{\mathrm{a}}$, \\ José I. NÚÑEZ ${ }^{\mathrm{a}, \mathrm{b}}$, Rufino FERNÁNDEZ ${ }^{\mathrm{a}}$, José M. SÁNCHEZ-VIZCAÍNO ${ }^{\mathrm{a}}$ \\ ${ }^{a}$ Centro de Investigación en Sanidad Animal, INIA, 28130 Valdeolmos, Madrid, Spain \\ ${ }^{\mathrm{b}}$ Centro de Biología Molecular "Severo Ochoa" (CSIC-UAM), Universidad Autónoma de Madrid, \\ 28049 Cantoblanco, Madrid, Spain
}

(Received 28 March 2002; accepted 23 August 2002)

\begin{abstract}
A reverse transcription-PCR (RT-PCR) method is presented for the highly sensitive and specific detection of foot-and-mouth disease virus (FMDV). A primer pair flanking a region of the viral polymerase gene (3D) corresponding to the C-terminus of the protein was designed and a single step RT-PCR reaction was developed. The assay allowed the detection of viral RNA from a variety of animal samples and from a wide range of FMDV isolates of different origins and serotypes. The presence of an Ahd I restriction site within the amplicon in $96 \%$ of the isolates analyzed allowed an additional confirmation step of the positive reactions by a simple digestion yielding characteristic fragment sizes. The set of primers described here was suitable for direct sequencing of the PCR product ( $290 \mathrm{bp}$ ), and the nucleotide sequences corresponding to the SAT 1 and SAT 3 strains were determined. The segment amplified, when used in phylogenetic studies, allowed the clustering of SAT isolates and the rest of FMDV strains as two separate lineages.
\end{abstract}

foot-and-mouth disease / direct RT-PCR / restriction enzyme analysis / sequence analysis

\section{INTRODUCTION}

Foot-and-mouth disease virus (FMDV) is the causal agent of an extremely contagious, widespread and economically devastating vesicular disease affecting clovenhoofed animals (mainly cattle, pigs, sheep, goats and buffalo) [5, 19]. As a member of the Picornaviridae family, genus
Aphthovirus [17], FMDV has a positive single-stranded RNA genome coding for the viral proteins which are expressed as a single polyprotein, subsequently processed by several viral proteases into the functional products. There are seven serotypes of the virus. Serotypes A, O and C, are widely distributed; serotypes SAT 1 , SAT 2 and SAT 3, are normally restricted to

\footnotetext{
* Correspondence and reprints

Tel.: (34) 91 6202300; fax: (34) 91 6202247; e-mail: saiz@inia.es
} 
sub-Saharan Africa, and serotype Asia 1 is restricted to Asia. There is considerable heterogeneity within each serotype and no cross-immunity has been found between the serotypes.

Effective control of the foot-and-mouth disease requires the early detection of infected animals even before the onset of the classical signs of the disease. This enables to discriminate between infected and uninfected herds and the subsequent elimination of infectious livestock. Tests based on RT-PCR are therefore assuming an important role for the laboratory detection of FMDV as an alternative to virus isolation tests which are time-consuming (up to 5 days) and require cell culture of the infectious virus, involving work at highsecurity laboratories. An effective distinction is as well required between FMDV and the two other viruses causing major indistinguishable vesicular diseases affecting swine [11]: swine vesicular disease virus (SVDV) [21] included in the Picornaviridae family, and vesicular stomatitis virus (VSV), a rhabdovirus restricted to the Americas [23]. Bovine viral diarrhea virus (BVDV), a pestivirus of the Flaviviridae family can induce a mucosal form of the disease in cattle which might also be confused with FMD [6].

In this study we present a highly sensitive and specific RT-PCR assay for the detection of FMDV isolates performed in a single step reaction. The primer set designed for the amplification brackets a segment of the viral RNA polymerase 3D gene and includes an Ahd I restriction site highly conserved among isolates that can be used as an additional confirmation step in a rapid digestion reaction following amplification. No cross-reactions were detected with SVDV, VSV and BVDV isolates. In order to explore the range of detection of our RT-PCR method, we tested 48 different FMDV isolates, and successfully detected the virus in samples from different fluids, tissues and organs from experimentally infected animals. Sequencing of the RT-PCR products using the same primers allowed reliable nucleotide sequence determination, and we report here new 3D sequence information obtained from SAT 1 and SAT 3 strains. In phylogenetic analysis, the 3D amplicon proved to contain an informative value, clustering SAT isolates independently from the rest of the FMDV strains.

\section{MATERIALS AND METHODS}

\subsection{Viruses}

The FMDV viral isolates used in this study are listed in Table I. SAT 1-3 and LEB/88 isolates were provided by the World Reference Laboratory for FMD, Institute for Animal Health (IAH), Pirbright Laboratory, UK. Except FMDV A5w (GER/48), A22 (IRQ 24/64), O1k (GER/60) and CS8 (SPA/70), all FMDV isolates were provided as vesicular epithelium samples from experimental infections and supernatant obtained after passage of the sample in cell culture by Scott Reid from IAH, Pirbright, UK. Other related viruses were used: SVDV isolates IT/66, UK/72, Alfort/73, SP1/93, SP2/93, ROM2/73, Italy $1083 / 92$, HKN 4/72 and HKN 25/91; the last four SVDV isolates were kindly provided by Emiliana Brocchi from the Istituto Zooprofilattico Sperimentale della Lombardia e dell'Emilia Romagna "B. Ubertini", Brescia, Italy. New Jersey and Indiana VSV serotypes, and the NADL BVDV strain were also included in the study.

\subsection{Experimental infection and sampling of the animals}

Two four month-old Landrace $\times$ Large White pigs were inoculated in the coronary matrix with $10^{5}$ PFU of FMDV $\mathrm{A}_{22}$ Iraq (IRQ 24/64). Sampling of nasal and pharynx secretions using cotton swabs and blood (sera) was done at 0, 1, 2 and 3 days post infection (pi). At 4 days pi the animals were anaesthetized for slaughtering and several tissues and organs were collected. 
Table I. Summary of the results obtained by RT-PCR using 3D-1/3D-2 or A/B primer sets on epithelial suspensions (ES) and supernatant fluid from the passage of ES in cell culture with the FMDV isolates used in this study.

\begin{tabular}{|c|c|c|c|c|c|}
\hline \multirow[b]{2}{*}{ Serotype } & \multirow[b]{2}{*}{ Isolate } & \multicolumn{2}{|c|}{$3 \mathrm{D}-1 / 3 \mathrm{D}-2$} & \multicolumn{2}{|c|}{$\mathrm{A} / \mathrm{B}$} \\
\hline & & Epithelial suspension & Cell culture fluid & Epithelial suspension & Cell culture fluid \\
\hline \multirow[t]{12}{*}{ A } & TUR 4/99 & + & + & + & + \\
\hline & IRN 1/97 & + & + & + & + \\
\hline & BRA 11/93 & - & + & + & + \\
\hline & SAU $19 / 92$ & + & + & + & + \\
\hline & GAM 46/98 & + & + & + & + \\
\hline & BRA 10/93 & - & - & + & + \\
\hline & SAU $17 / 92$ & + & + & + & + \\
\hline & TUR $10 / 88$ & + & + & + & + \\
\hline & ERI 3/98 & - & - & + & + \\
\hline & MCD 6/96 & + & + & + & + \\
\hline & IRQ 24/64 & + & + & + & + \\
\hline & GER/48 & NA & + & NA & + \\
\hline \multirow[t]{11}{*}{$\mathrm{O}$} & SAU 72/94 & + & + & + & + \\
\hline & TUR 3/87 & + & + & + & + \\
\hline & PHI 13/95 & + & + & + & + \\
\hline & GRE 21/94 & + & + & + & + \\
\hline & TUR 3/94 & + & + & + & + \\
\hline & KUW 4/97 & + & + & + & + \\
\hline & BRA 4/94 & + & + & + & + \\
\hline & SAU 8/88 & + & + & + & + \\
\hline & IRN $15 / 97$ & + & + & + & + \\
\hline & KUW 3/88 & - & - & + & + \\
\hline & GER/60 & NA & + & NA & + \\
\hline \multirow[t]{11}{*}{$\mathrm{C}$} & PHI 2/90 & - & + & + & + \\
\hline & ITL 2/88 & + & + & + & + \\
\hline & PHI 3/87 & + & + & + & + \\
\hline & GER 26 & + & + & + & + \\
\hline & BEL 1/69 & + & + & + & + \\
\hline & LEB 9/69 & + & + & + & + \\
\hline & BEL 53 & + & + & + & + \\
\hline & SRL 4/88 & + & + & + & + \\
\hline & ANG 3/73* & - & + & - & + \\
\hline & BRA 55 & + & + & + & + \\
\hline & SPA/70 & NA & + & NA & + \\
\hline \multirow[t]{11}{*}{ Asia 1} & BUR 12/77 & + & + & + & + \\
\hline & CAM 3/93 & + & + & + & + \\
\hline & PAK $2 / 98$ & + & + & + & + \\
\hline & IRN 58/99* & + & + & + & + \\
\hline & IND 10/82 & + & + & + & + \\
\hline & PAK 3/98 & + & + & + & + \\
\hline & SAU 39/94 & + & + & + & + \\
\hline & TUR 15/73 & + & + & + & + \\
\hline & KUW 2/81 & + & + & + & + \\
\hline & NEP 58/88 & + & + & + & + \\
\hline & $\mathrm{LEB} / 88$ & + & + & + & + \\
\hline SAT 1 & $2 / 54$ & NA & - & NA & + \\
\hline SAT 2 & RHO 1/48 & NA & - & NA & + \\
\hline SAT 3 & RV 7/34 & NA & - & NA & + \\
\hline
\end{tabular}

NA: not available.

* Isolate yielding A/B RT-PCR product resistant to Ahd I digestion. 


\subsection{Virus titration}

Virus infectivity was determined by titration of tissue culture FMDV isolates O1k (GER/60) and SAT 1 (2/54) in IBRS2 monolayers. The cells were cultured in Dulbecco's modified Eagle's medium supplemented with $5 \%$ foetal bovine serum. Basically, serial dilutions of the isolates in a 500- $\mu \mathrm{L}$ volume were added to $2 \times$ $10^{6}$ cells, incubated for $1 \mathrm{~h}$ at $37{ }^{\circ} \mathrm{C}$ and vigorously shaken every $15 \mathrm{~min}$. Then, the inoculum was removed and the cells were kept at $37{ }^{\circ} \mathrm{C}$ under $0.6 \%$ agar overlay. Monolayers were fixed and stained $24 \mathrm{hpi}$. The infections were performed on duplicates. Resulting plaques were scored and referred to the volume of the inoculum (PFU/mL).

\subsection{RNA extraction}

Total RNA was extracted with Tri Reagent (Sigma-Aldrich, Steinheim, Germany) from supernatants of virus-infected cells (BHK-21 and IBRS-2) according to the manufacturer's recommendations. Pharynx and nose swabs were solubilized in $1 \mathrm{~mL}$ of phosphate-buffered saline (PBS) prior to RNA extraction. Sera samples were extracted without any further manipulation. Alternatively, 10-fold dilutions in PBS of homogenates from different tissues and organs analyzed were extracted.

\subsection{Primers}

Primers A (5'-CACACGGCGTTCA CCCA(A/T)CGC-3') and B (5'-GACAAA GGTTTTGTTCTTGGTC-3') were designed to bracket a 290-bp region in the 3D polymerase gene, based on an alignment of the available FMDV sequences using CLUSTALW 1.8 software (Fig. 1). The EMBL accession numbers for the sequences shown in Figure 1 were as follows: CS8, M11027; C rp146, AJ133359; O Chu-pei, AF026168; O Taiwan, AF154271; O1 Geshur, AF189157; A10-
61, X00429; O1k, X00871; C3 Arg 85, AJ007572; A12, M10975; A5Ww, AJ010871; A22-645, X85493; A22/550, X74812, Asia 1, AF207520, and SAT 2, AJ251473. Sequences in the region analyzed for SAT 1 and SAT 3 were not available and were determined following RTPCR amplification and were included in the alignment shown in Figure 1.

The previously described primers 3D-1 and 3D-2 [15] were used in comparative detection tests.

\subsection{RT-PCR}

Aliquots of viral RNA $(2 \mu \mathrm{L})$ were added to a single step RT-PCR reaction containing $2.5 \mu \mathrm{L}$ of $10 \times$ PCR buffer II (Perkin-Elmer, Branchburg, NJ, USA), $2 \mu \mathrm{L}$ of $25 \mathrm{mM} \mathrm{MgCl} 2,0.5 \mu \mathrm{L}$ of a desoxynucleotide triphosphate mixture (each at $10 \mathrm{mM}$; Roche, Indianapolis, IN, USA), $0.25 \mu \mathrm{L}(5 \mathrm{U})$ of RNase Inhibitor (PerkinElmer, Branchburg, NJ, USA), $0.25 \mu \mathrm{L}$ (12.5 U) of MuLV Reverse Transcriptase (Perkin-Elmer, Branchburg, NJ, USA Branchburg, NJ, USA), $0.125 \mu \mathrm{L}$ (0.6 U) of AmpliTaq Gold (Perkin-Elmer, Branchburg, NJ, USA), 5-10 pmol of each primer and RNase-free water to a final volume of $25 \mu \mathrm{L}$. Amplification was performed on a PTC-100 Programmable Thermal Controller (MJ Research Inc., Waltham, MA, USA).

The cycling parameters were initial incubation at $48{ }^{\circ} \mathrm{C}$ for $30 \mathrm{~min}$ and $95{ }^{\circ} \mathrm{C}$ for $10 \mathrm{~min}$; then 35 cycles consisting of $94{ }^{\circ} \mathrm{C}$ for $30 \mathrm{~s}, 60^{\circ} \mathrm{C}$ for $45 \mathrm{~s}$ and $72{ }^{\circ} \mathrm{C}$ for $45 \mathrm{~s}$, and then a final incubation at $72{ }^{\circ} \mathrm{C}$ for $7 \mathrm{~min}$. Following RT-PCR, a $12-\mu \mathrm{L}$ volume of each reaction was subjected to electrophoresis on a $2 \%$ agarose gel containing ethidium bromide.

RT-PCR assays using 3D-1 and 3D-2 primers were performed as described [15].

\subsection{Restriction enzyme digestion}

RT-PCR reactions in which amplicons with primers $\mathrm{A} / \mathrm{B}$ were detected were 

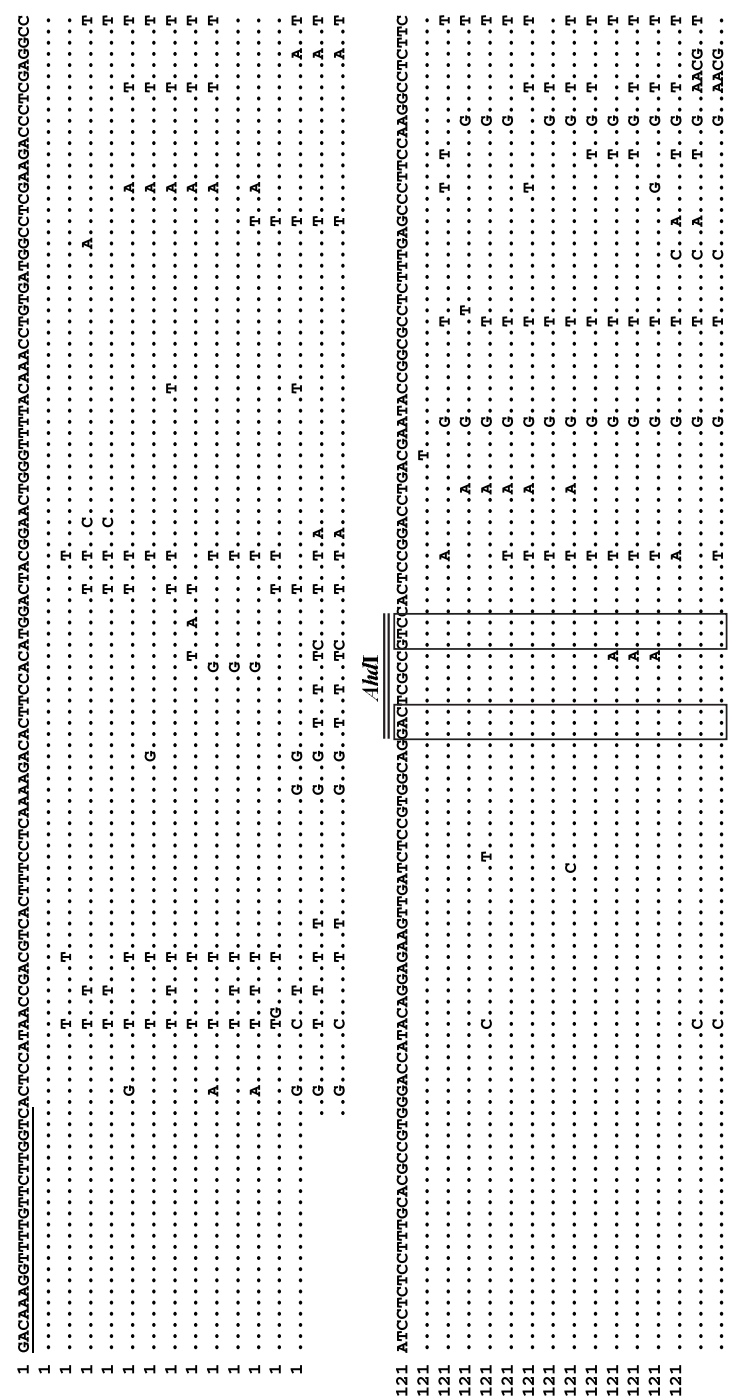

U⿺乚一匕

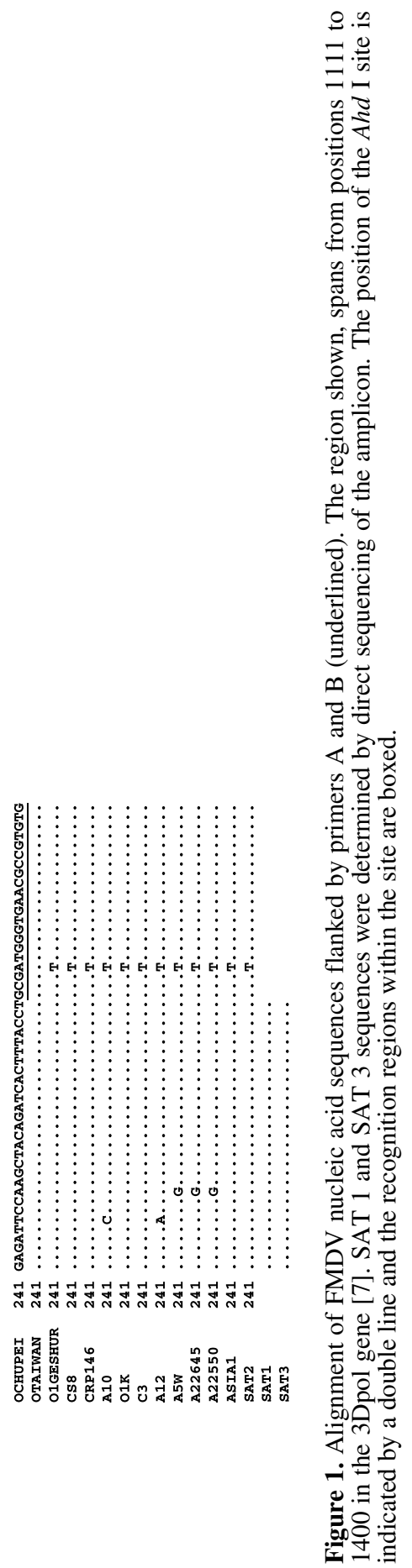




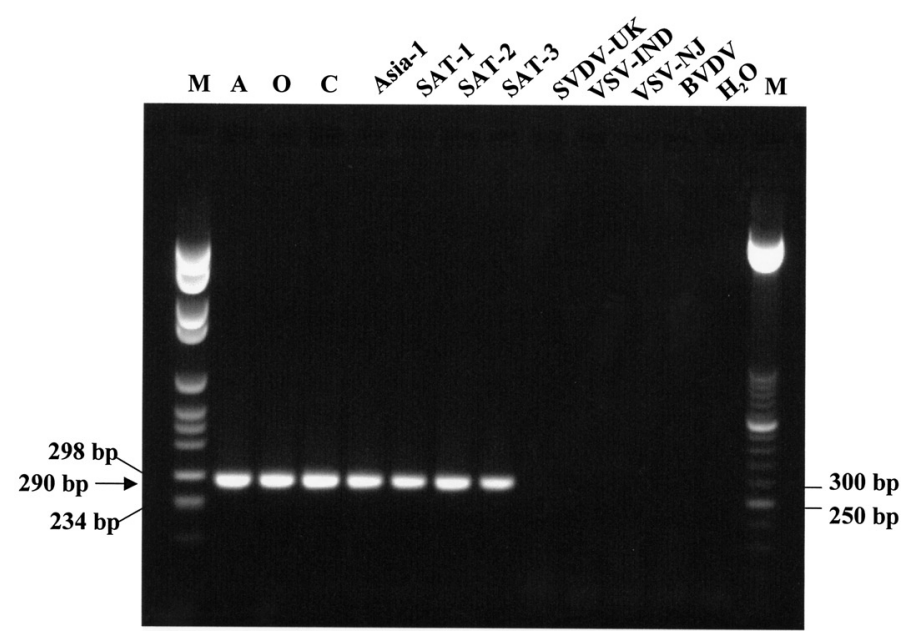

Figure 2. Specificity of primers A/B for FMDV detection. Cell culture isolates representative of each serotype and other related viruses were assayed by RT-PCR and analyzed in $2 \%$ agarose gels. The expected size band is indicated by an arrow. M, markers.

subjected to digestion with Ahd I (New England Biolabs, Beverly, MA, USA). The digestion mixture consisted of $10 \mu \mathrm{L}$ of the RT-PCR reaction and $2 \mathrm{U}$ of the enzyme. The reaction mixtures were incubated for $1 \mathrm{~h}$ at $37^{\circ} \mathrm{C}$ and then loaded onto a $2.5 \%$ agarose gel. The expected sizes of the digestion products were 181 and $109 \mathrm{bp}$, respectively.

\subsection{Sequencing}

Following RT-PCR, amplicons obtained from SAT 1 and SAT 3 FMDV strains were excised from agarose gel, purified with an Agarose Gel DNA Extraction Kit (Roche, Indianapolis, IN, USA) and subjected to sequencing reactions in both directions with an fmol DNA Cycle Sequencing System (Promega, Madison, WI, USA).

\subsection{Phylogenetic analysis}

Sequences flanked by primers A and B, including all the isolates shown in Figure 1, were used to derive a phylogenetic tree using the neighbor-joining method [18].

\section{RESULTS}

\subsection{Development and specificity of the detection method}

By using the available sequence information, we selected primers $\mathrm{A}$ and $\mathrm{B}$ to amplify a 290-bp fragment of the 3Dpol gene corresponding to the $\mathrm{C}$-terminus of the protein (Fig. 1). The results of the RTPCR reactions with different isolates corresponding to all seven FMDV serotypes are shown in Figure 2. A unique band of the expected size was observed in the lanes corresponding to FMDV isolates. No amplification product was observed in the samples from SVDV, VSV or BVDV, indicating that the $\mathrm{A}$ and $\mathrm{B}$ primers did not cross-hybridize with the genomes of these clinically related viruses. Several SVDV isolates (Materials and Methods) were included as control reactions to rule out the possibility of detection interference with this related swine picornavirus, giving all of them negative results (data not shown).

To confirm the positive results of our detection assay, as many as 48 different 


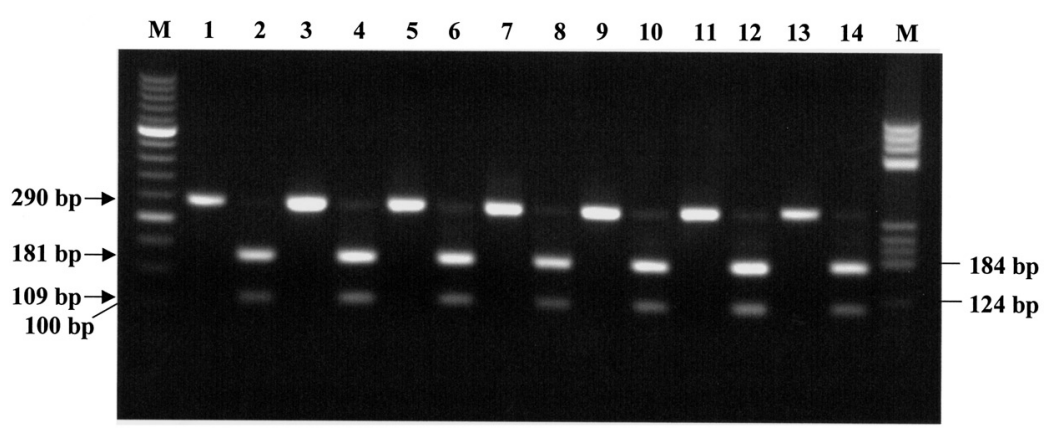

Figure 3. Restriction digestion with Ahd I of RT-PCR products from FMDV isolates. Digestion reaction mixtures were electrophoresed on $2.5 \%$ agarose gels. Odd number lanes show the undigested RT-PCR products. Even number lanes show the results of incubation of the amplicons with Ahd I . Lanes 1 and 2, FMDV A5w (GER/48); lanes 3 and 4, FMDV O1k (GER/60); lanes 5 and 6, FMDV Cs8 (SPA/70); lanes 7 and 8, FMDV Asia 1 (LEB/88); lanes 9 and 10, FMDV SAT 1 (2/54); lanes 11 and 12, FMDV SAT 2 (RHO 1/48); lanes 13 and 14, FMDV SAT 3 (RV 7/34). The undigested RT-PCR product and the expected size of the digestion products are indicated by arrows. M, markers.

FMDV isolates (Tab. I) of very diverse origin and sequences, were tested with primers $\mathrm{A} / \mathrm{B}$ giving positive results yielding the expected-size amplicon (data not shown). These isolates were assayed as both vesicular epithelium samples and their corresponding cell culture supernatants. Only one of these isolates (ANG 3/ 73) could not be detected in the epithelium sample but was readily detected in the supernatant resulting from passage in cell culture (Tab. I). Analysis of the FMDV samples with the previously described primers 3D-1/3D-2 failed to detect 6 of the epithelium samples and 3 of the corresponding cell culture supernatants. Moreover, none of the 3 SAT-serotypes isolate could be detected with the 3D-1/3D-2 primers (Tab. I).

\subsection{Restriction enzyme digestion}

Alignment of the sequences flanked by the A/B primers (Fig. 1) showed the presence of an Ahd I site (GACNNN/NNGTC) in the RT-PCR products. The predicted size for the restriction fragments after Ahd I digestion were 109 and $181 \mathrm{bp}$ respectively, easily detectable by electrophoresis in agarose gels. Since the sequence information for the 3Dpol gene was limited among the FMDV isolates, we tested the presence of the Ahd I site empirically. Amplicons obtained by RT-PCR from FMDV isolates were subjected to restriction endonuclease digestion with Ahd I. After digestion and electrophoresis, viral cDNAs corresponding to all seven serotypes yielded the fragment pattern predicted by sequence analysis, as shown in Figure 3. To assess the degree of conservation of the Ahd I site among FMDV isolates, all 48 isolates used in the study, and successfully amplified with primers $\mathrm{A} / \mathrm{B}$, were inspected for the presence of the Ahd I site in their RT-PCR products. Only 2 isolates (Tab. I) yielded amplicons which remained undigested in the presence of the enzyme (data not shown). Although the absence of the Ahd I site sequence remains to be determined, the high conservation of this target $(96 \%)$ supports its use as a specificity marker. In all the Ahd I-digested amplicons the 108/181 bp pattern was confirmed.

\subsection{Sensitivity}

The sensitivity of the RT-PCR assay with the A/B primer pair was assessed for 


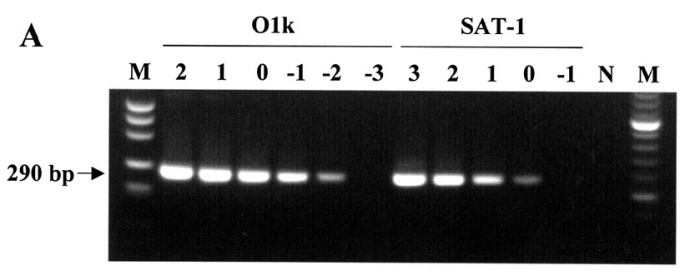

B
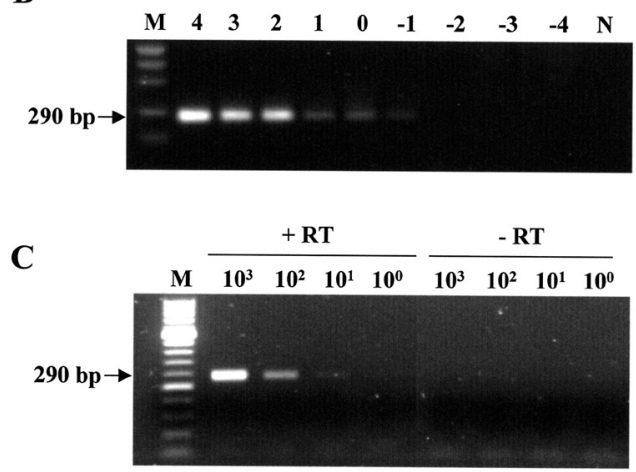

Figure 4. Detection limit of FMDV RNA by RT-PCR with primers A/B. (A) Serial dilutions of RNA extracted from cell culture: $10^{2}$ to $10^{-3} \mathrm{PFU}$ of FMDV O1k and $10^{3}$ to $10^{-1} \mathrm{PFU}$ of FMDV SAT 1 (2/54). (B) FMDV O1k (GER/60) RNA extracted independently from serial dilutions of virus $\left(10^{4}\right.$ to $10^{-4} \mathrm{PFU}$ ). (C) Serial dilutions (from $10^{3}$ to $10^{0} \mathrm{fg}$ ) of full-length FMDV O1k RNA. In (-) RT lanes, reverse transcriptase was not added to the reaction mixture. RT-PCR products were analyzed by $2 \%$ agarose gel electrophoresis. $\mathrm{N}$, negative control (uninfected). M, marker.

two FMDV isolates belonging to genetically and geographically divergent groups of isolates. O1k (GER/60) is a well characterized isolate at the molecular and clinical level, while for FMDV SAT 1 (2/54) there is little sequence information available. The sensitivity assay was performed by serial dilutions of RNA initially extracted from the cell culture supernatant. Independently, serial dilutions of the infected cell culture supernatant were used for RNA extractions. For serial dilutions of an initially extracted FMDV RNA, the detection limit corresponded to $10^{-2} \mathrm{PFU}$ for the $\mathrm{O} 1 \mathrm{k}$ isolate and $1 \mathrm{PFU}$ for the SAT 1 isolate (Fig. 4A). When FMDV O1k RNA extractions were performed independently for each serial dilution, the detection limit was $10^{-1}$ PFU (Fig. 4B). The capacity of detection of quantified FMDV RNA was assessed using full-length O1k RNA transcripts (Fig. 4C). The detection limit was $10 \mathrm{fg}$ of RNA. The absence of template DNA interfering in the amplification was confirmed by (-) RT reactions.

\subsection{Detection of FMDV in samples from experimentally infected pigs}

Animal samples taken from 0 to 4 days pi were assayed for the presence of FMDV RNA. Table II shows the results of FMDV detection in several tissue samples using both $\mathrm{A} / \mathrm{B}$ and $3 \mathrm{D}-1 / 3 \mathrm{D}-2$ primers. Pigs 1 and 2 developed clinical signs of disease (foot lesions) on days 3 and 4 pi, respectively. We were able to detect the virus in sera as early as 1 day pi with the primers A/ B. When using the $3 \mathrm{D}-1 / 3 \mathrm{D}-2$ primers, FMDV could only be detected in the sera 
Table II. Detection of FMDV by RT-PCR from tissue samples of experimentally infected pigs with the primers 3D-1/3D-2 [15] (a) and A/B (b).

\begin{tabular}{|c|c|c|c|c|c|c|c|c|c|c|c|}
\hline \multirow[b]{3}{*}{ Sample } & & \multicolumn{10}{|c|}{ Days Post Infection } \\
\hline & & 0 & 1 & 2 & 3 & 4 & 0 & 1 & 2 & 3 & 4 \\
\hline & & \multicolumn{5}{|c|}{ Pig 1} & \multicolumn{5}{|c|}{ Pig 2} \\
\hline \multirow[t]{2}{*}{ Sera } & (a) & - & - & + & + & - & - & - & - & + & + \\
\hline & (b) & - & + & + & + & + & - & + & + & + & + \\
\hline \multirow{2}{*}{$\begin{array}{l}\text { Pharynx } \\
\text { Swab }\end{array}$} & (a) & - & - & - & + & + & - & - & - & + & + \\
\hline & (b) & - & - & - & + & + & - & - & - & + & + \\
\hline \multirow[t]{2}{*}{ Nose Swab } & (a) & - & - & + & + & + & - & - & - & + & + \\
\hline & (b) & - & - & + & + & + & - & - & + & + & + \\
\hline \multirow[t]{2}{*}{ Liver } & (a) & & & & & - & & & & & - \\
\hline & (b) & & & & & - & & & & & - \\
\hline \multirow[t]{2}{*}{ Spleen } & (a) & & & & & + & & & & & - \\
\hline & (b) & & & & & + & & & & & + \\
\hline \multirow[t]{2}{*}{ Heart } & (a) & & & & & + & & & & & NA \\
\hline & (b) & & & & & + & & & & & NA \\
\hline \multirow[t]{2}{*}{ Lymph Nodes } & (a) & & & & & NA & & & & & - \\
\hline & (b) & & & & & NA & & & & & + \\
\hline \multirow[t]{2}{*}{ Kidney } & (a) & & & & & - & & & & & - \\
\hline & (b) & & & & & - & & & & & - \\
\hline \multirow[t]{2}{*}{ Tonsil } & (a) & & & & & + & & & & & - \\
\hline & (b) & & & & & + & & & & & + \\
\hline \multirow{2}{*}{$\begin{array}{l}\text { Vesicular } \\
\text { Epithelium }\end{array}$} & (a) & & & & & + & & & & & + \\
\hline & (b) & & & & & + & & & & & + \\
\hline
\end{tabular}

NA: not available.

after 2 or 3 dpi depending on the animal. Nose swab samples gave positive results on day 2 pi and pharynx swabs on day 3 pi with the $\mathrm{A} / \mathrm{B}$ primers. In pig 2 , the virus was detected in nose swab samples on day 3 pi with the 3D-1/3D-2 primers. When the pigs were slaughtered on day 4 pi, a variety of samples were taken from different organs to test the presence of the virus. As shown in Table II, FMDV was detected in the spleen, heart, lymph nodes, tonsils and vesicular epithelium from foot lesions. Primers 3D-1/3D-2 failed to detect FMDV in the spleen, lymph nodes and tonsils from pig 2 . The virus was not detected in the liver and kidney.

\subsection{Sequence and phylogenetic analysis}

RT-PCR with primers A/B enabled the direct sequencing of SAT 1 and SAT 3 amplicons. The new sequences were included in the alignment performed previously using the available sequence data (Fig. 1). All sequences shown in this alignment, immediately adjacent to the sequence of primers $\mathrm{A}$ and $\mathrm{B}$, and corresponding to different FMDV isolates and strains, were subjected to phylogenetic analysis. The dendrogram obtained is depicted in Figure 5. Two different clusters, including the SAT isolates and the rest 


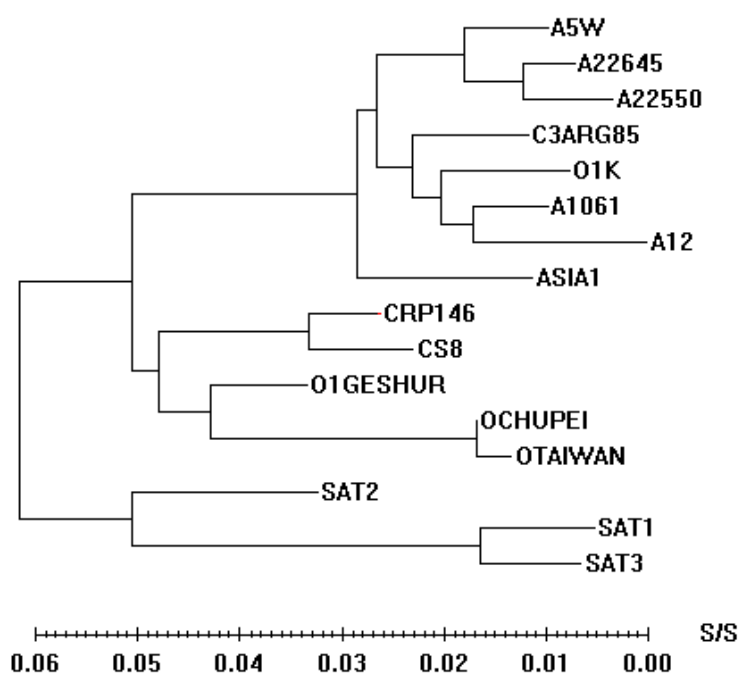

Figure 5. A phylogenetic tree derived from nucleotide sequences flanked by the primer pair A/B corresponding to FMDV isolates shown in Figure 1. Vertical distances are arbitrary and horizontal distances represent the number of substitutions per site $(\mathrm{S} / \mathrm{S})$.

of the FMDV isolates, respectively, can be clearly identified. This proves the divergent nature of the South African FMDV strains, showing marked genomic and antigenic variation.

\section{DISCUSSION}

Early and specific diagnosis of FMD represents an essential tool for the control of the disease. As shown in the recent UK outbreak [10], this highly contagious disease can spread rapidly in an area where infected animals have been introduced, travelling easily to other regions and countries through direct or indirect contact between livestock. The threat represented by the disease now in Europe illustrates how an old-known disease considered basically eradicated can strike back with devastating economical consequences, involving massive slaughtering of herds and introducing trade restrictions on animals and livestock products.

New strategies based on RT-PCR assays are being applied to develop rapid and sensitive detection tests for FMDV [1, $2,8,12]$. These protocols are an alternative or are complementary to the classical serological and viral isolation assays due to their higher sensitivity and speed and the fact that the handling of infectious viruses is not required. The main challenge found for the design of primers suitable for diagnosis has been the genetic diversity of the virus, which complicates both the efficient universal amplification of all isolates and their serotyping using specific primers, and requiring complex combinations of oligonucleotides and protocols. Various serotype-specific primer pairs have been used for the amplification of genomic regions in order to type FMDV isolates [3, 15]. RT-PCR protocols with immunocapture techniques [20] or preceded by direct adsorption of the virus to microtiter plates [16] have also been developed. Universal primers based on the $2 \mathrm{~B}$ gene sequence have been reported $[14,22]$, and, in order to match virus isolation sensitivity, a nested RT-PCR was developed for FMDV detection in clinical samples [9]. Non-coding regions of the viral genome have also 
been used as targets for primer design with serotype-dependent efficiency [13].

We describe here a single-tube RT-PCR assay, coupled with digestion with a restriction enzyme, for sensitive and reliable amplification of FMDV isolates. The primers designed are anchored in highly conserved regions of the $3 \mathrm{D}$ polymerase gene, less susceptible to nucleotide changes than capsid protein coding regions, subjected to immunological pressure and host selection [15]. Primers A/B were able to amplify a 290-bp fragment in FMDV samples. It was indeed shown that viral RNA from every FMDV isolate tested (as many as 48) was amplified and no cross-hybridization was observed with the viruses genetically or clinically related to FMDV. Detection of the virus from diverse clinical samples at early times postinfection suggest the suitability of the assay as a valuable tool for FMDV detection.

Compared with primers $\mathrm{A} / \mathrm{B}$, previously described primers 3D-1/3D-2 [15], designed to amplify a 209-bp fragment of the $3 \mathrm{Dpol}$ gene corresponding to the C-terminus of the protein, exhibited an impaired capacity for FMDV detection. Among the FMDV-positive samples tested, 6 epithelia and 3 cell culture supernatants failed to be detected, including the 3 SAT-serotype isolates. These results were confirmed by the detection analysis from clinical samples, since 3D-1/3D-2 primers failed to detect the virus in some organs and showed a 1 to 2 day delay in detection from the sera.

The amplification reaction with $\mathrm{A} / \mathrm{B}$ primers exhibited a high detection limit, $10 \mathrm{fg}$ of viral RNA, and $10^{-2}$ PFU for a $\mathrm{O} 1 \mathrm{k}$ isolate. A remarkable improvement in sensitivity has been achieved with the assay described here as compared to the ELISA detection limit of $1.8 \times 10^{4} \mathrm{PFU}$ for serotype $\mathrm{O}$ isolates in our hands, using the OIE/FAO recommended method, and PCR detection limit of 3 PFU with primers 3D1/3D-2 [15]. However, some differences in sensitivity were found among the two isolates analyzed (1 PFU for the SAT 1 isolate). Since they belong to genetically divergent groups, and the sequences corresponding to the primer annealing regions for SAT 1 and SAT 3 are not available, the presence of mismatches in these regions, as well as differences in the efficiency of RNA extraction and/or titration of the isolates, cannot be ruled out and contribute to the lower sensitivity in detection of the SAT 1 isolate as compared to that of O1k. Additionally, the ratio between infectious particles (measured as PFU) and amplifiable RNA may vary among different isolates and samples. Inter-serotype differences in the sensitivity of detection are as well found using ELISA $\left(2.3 \times 10^{3} \mathrm{PFU}\right.$ for $\mathrm{C}$ serotype isolates, data not shown).

The possibility of sequence confirmation by restriction digestion with the Ahd I enzyme, which works well without having to purify the amplicon from the RT-PCR mixture, and resulting in two fragments easy to identify by gel electrophoresis, is an additional advantage to the method. Moreover, nucleotide sequence data are easy and rapid to obtain from the amplicons using the same set of primers. SAT 1 and SAT 3 sequences corresponding to the amplified 3D fragment were determined within one day.

Sequences flanked by primer pair A/B including all seven FMDV serotypes were used to derive a phylogenetic tree. The dendrogram obtained shows the segregation of the SAT isolates into an independent group, with SAT 1 and SAT 3 being more closely related among them than the SAT 2 strain. It is remarkable that a $290 \mathrm{nt}$ window of a relatively conserved gene (3D) contains an informative value to allow the independent clustering of the two main, geographically and genetically divergent viral isolates. A similar cluster for SAT isolates was found when the highly variable VP1 gene (capsid protein component) sequences were used in the phylogenetic analysis [4]. 
In summary, we have described a rapid, sensitive and specific method for FMDV detection, well-suited for clinical samples and isolate clustering. Future work in the lab will be focused on the development of real time PCR technology with primers A/ $\mathrm{B}$ and analysis of sheep samples.

\section{ACKNOWDLEGMENTS}

This research was supported by INIA-DGG (cc-97/129) and the Spanish Ministry of Defense (DGAM). The authors wish to acknowledge HIPRA, S.A., J. L. Arceiz and L. Martín-Otero (Laboratorio N.B.Q., Fábrica Nacional La Marañosa) for their contribution to the project, and F. Sobrino for helpful discussions and critical reading of the manuscript.

\section{REFERENCES}

[1] Alexandersen S., Forsyth M.A., Reid S.M., Belsham G.J., Development of reverse transcription-PCR (Oligonucleotide probing) enzyme-linked immunosorbent assays for diagnosis and preliminary typing of foot-andmouth disease: a new system using simple and aqueous-phase hybridization, J. Clin. Microbiol. 38 (2000) 4604-4613.

[2] Alexandersen S., Oleksiewick M.B., Donaldson, A.I., The early pathogenesis of foot-and-mouth disease in pigs infected by contact: a quantitative time-course study using TaqMan RT-PCR, J. Gen. Virol. 82 (2001) 747-755.

[3] Callens M., De Clercq K., Differentiation of the seven serotypes of foot-and-mouth disease virus by reverse transcriptase polymerase chain reaction, J. Virol. Methods 67 (1997) 35-44.

[4] Dopazo J., Rodrigo M.J., Rodríguez A., Sáiz J.C., Sobrino F., Apthovirus evolution, in: Gibbs A., Calisher C.H. (Ed.), Molecular Evolution of Viruses, Cambridge University Press, Cambridge. 1994, pp. 310-320.

[5] Kitching R.P., Foot-and-mouth disease: current world situation, Vaccine 26 (1999) 1772 1774.

[6] Mann J., Sellers R., Foot-and-mouth disease virus, in: Horzinek M. (Ed.), Virus Infections of Vertebrates, Elsevier, Amsterdam Oxford New York Tokyo, 1990, pp. 503-512.

[7] Martínez-Salas E., Ortín J., Domingo E., Sequence of the viral replicase gene from foot-and-mouth disease virus $\mathrm{C}_{1}$-Santa Pau (C-S8), Gene 35 (1985) 55-61.

[8] Meyer R.C., Brown C., House C., House J., Molitor T., Rapid and sensitive detection of foot-and-mouth disease virus in tissues by enzymatic RNA amplification of the polymerase gene, J. Virol. Methods 34 (1991) 161-172.

[9] Moss A., Haas B., Comparison of the plaque test and reverse transcription nested PCR for the detection of FMDV in nasal swabs and probang samples, J. Virol. Methods 80 (1999) 59-67.

[10] Knowles N.J., Samuel A.R., Davies P.R., Kitching R.P., Donaldson A.I., Outbreak of foot-and-mouth disease virus serotype $\mathrm{O}$ in the UK caused by a pandemic strain, Vet. Rec. 148 (2001) 258-259.

[11] Núñez J.I., Blanco E., Hernández T., GómezTejedor C., Martín M.J., Dopazo J., Sobrino F., A RT-PCR assay for the differential diagnosis of vesicular viral diseases of swine, J. Virol. Methods 72 (1998) 227-235.

[12] Oleksiewick M.B., Donaldson A.I., Alexandersen S., Development of a novel real-time RT-PCR assay for quantitation of foot-and-mouth disease virus in diverse porcine tissues, J. Virol. Methods 92 (2001) 23-35.

[13] Reid S.M., Ferris N.P., Hutchings G.H., Samuel A.R., Knowles N.J., Primary diagnosis of foot-and-mouth disease by reverse transcription polymerase chain reaction, J. Virol. Methods 89 (2000) 167-176.

[14] Reid S.M., Hutchings G.H., Ferris N.P., De Clercq K., Diagnosis of foot-and-mouth disease by RT-PCR: evaluation of primers for serotypic characterisation of viral RNA in clinical samples, J. Virol. Methods 83 (1999) 113-123.

[15] Rodríguez A., Martínez-Salas E., Dopazo J., Dávila M., Sáiz J.C., Sobrino F., Primer design for specific diagnosis by PCR of highly variable RNA viruses: typing of footand-mouth disease virus, Virology 189 (1992) 363-367.

[16] Rodríguez A., Núñez J.I., Nolasco G., Ponz F., Sobrino F., De Blas C., Direct PCR detection of foot-and-mouth disease virus, J. Virol. Methods 47 (1994) 345-349.

[17] Rueckert R.R., Picornaviridae: the viruses and their replication, in: Fields B.N., Knipe D.M., Howley P.M., (Ed.), Fields Virology, 3rd ed., Lippincott-Raven, Philadelphia, 1995.

[18] Saitou N., Nei M., The neighbour-joining method: a new method for reconstructing phylogenetic trees, Mol. Biol. Evol. 4 (1987) 406-425.

[19] Sobrino F., Sáiz M., Jiménez-Clavero M.A., Núñez J.I., Rosas M.F., Baranowski E., 
Ley V., Foot-and-mouth disease virus: an old, well know virus, and still a current threat, Vet. Res. 32 (2001) 1-30.

[20] Suryanarayana V., Madanamohan B., Bist P., Natarajan C., Tratschin J.D., Serotyping of foot-and-mouth disease virus by antigen capture reverse transcriptase/polymerase chain reaction, J. Virol. Methods 80 (1999) 45-52.

[21] Sutmoller P., Vesicular diseases, foreign animal diseases, in: Committee report on foreign animal diseases of the United States Animal Health Association. FAO, Richmond, VA, USA, 1992, pp. 368-382.
[22] Vangrysperre W., De Clercq K., Rapid and sensitive polymerase chain reaction based detection and typing of foot-and-mouth disease virus in clinical samples and cell culture isolates, combined with a simultaneous differentiation with other genomically and/or symptomatically related viruses, Arch. Virol. 141 (1996) 331-344.

[23] Wagner R.R., Rose J.K., Rhabdoviridae: the viruses and their replication, in: Fields B.N., Knipe D.M., Howley P.M. (Ed.), Fields Virology, 3rd ed., Lippincott-Raven, Philadelphia, 1995. 
